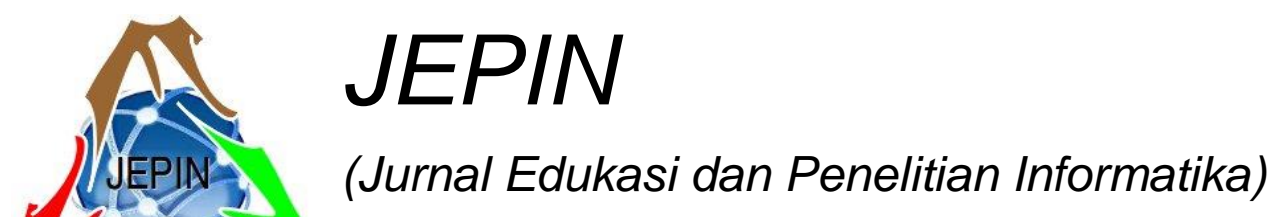

Vol. 6

No. 2

ISSN(e): 2548-9364 / ISSN(p) : 2460-0741

\title{
Uji Keberhasilan Implementasi Master Plan Teknologi Informasi dan Manajemen BDPJN Menggunakan Metode DeLone dan McLean
}

\author{
Agnes Sondita Payani ${ }^{\# 1}$, Gusti Darma Yudha ${ }^{\# 2}$, Siti Desty Wahyuningsih ${ }^{\# 3}$, Novranza Kannia ${ }^{* 4}$, \\ Diyoga Silavani Kusapy ${ }^{* 5}$, Dumaria Simanjuntak ${ }^{* 6}$, Yurisce Widya Bakaru*7, Sonia Simanullang*8 \\ \#Pusat Teknologi dan Data Penginderaan Jauh, LAPAN \\ Jl. Lapan No. 70, Kel. Pekayon, Kec. Pasar Rebo, Jakarta Timur

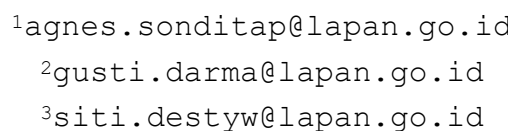 \\ *Fakultas Teknologi Informasi, Universitas Bina Sarana Informatika \\ Jl. Margonda Raya No.8, Pondok Cina, Kecamatan Beji, Kota Depok, Jawa Barat \\ ${ }^{4}$ novranzakannia@gmail.com \\ ${ }^{5}$ kusapydiyoga@gmail.com \\ ${ }^{6}$ kristinasimanjuntakk15@gmail.com \\ 7 yuriscewb@gmail.com \\ ${ }^{8}$ soniasimanullang208@gmail.com
}

\begin{abstract}
Abstrak - Dalam perjalanan operasional data penginderaan jauh di Pustekdata, LAPAN mengoperasikan Bank Data Penginderaan Jauh Nasional (BDPJN) yang gunanya untuk memfasilitasi kebutuhan data penginderaan jauh nasional. Pada tahun 2011, Pustekdata menyusun Master Plan dan Blue Print Teknologi Informasi (TI) BDPJN tahun 2012. 2016 dan Master Plan Manajemen BDPJN. BDPJN memiliki target yang tertuang pada Master Plan TI dan Manajemen BDPJN. Diperlukan suatu kajian untuk mengevaluasi apakah kegiatan yang telah dioperasionalkan hingga saat ini sudah menyesuaikan dengan implementasi dari Master Plan yang telah dibangun. Target-target yang tercantum pada Master Plan TI dan Manajemen BDPJN dapat dijadikan parameter untuk mengukur keberhasilan implementasi Master Plan TI dan Manajemen BDPJN yang telah dioperasionalkan hingga saat ini. Metode DeLone dan McLean digunakan untuk mengukur keberhasilan implementasi Master Plan TI dan Manajemen BDPJN. Koefisien korelasi yang dihasilkan dari pengujian menggunakan metode DeLone dan McLean menunjukkan bahwa kepuasan pengguna sangat berpengaruh pada kesuksesan implementasi masterplan BDPJN diikuti dengan meningkatnya kualitas sistem, kualitas layanan, dan kualitas informasi yang juga ikut mempengaruhinya. Selain itu, meningkatnya kepuasan pengguna maka akan berdampak pada manfaat-manfaat yang diberikan oleh sistem BDPJN sehingga dapat membantu meningkatkan dan mempermudah kinerja pegawai.
\end{abstract}

Kata kunci - DeLone dan McLean, BDPJN, Master Plan TI, Master Plan Manajemen, Uji Keberhasilan, Implementasi Master Plan

\section{Pendahuluan}

Lembaga Penerbangan dan Antariksa Nasional (LAPAN) merupakan Lembaga Pemerintah NonKementerian (LPNK) yang telah berdiri sejak tanggal 31 Mei 1962. Berdasarkan Perpres No. 49 tahun 2015 dan Peraturan Kepala LAPAN No. 8 tahun 2015 LAPAN berada di bawah Presiden Republik Indonesia dan bertanggung jawab melalui Menteri yang membidangi urusan pemerintahan di bidang riset dan teknologi [1]. LAPAN memiliki tugas pokok melaksanakan tugas pemerintahan di bidang penelitian dan pengembangan kedirgantaraan dan pemanfaatannya serta penyelenggaraan keantariksaan sesuai dengan ketentuan peraturan perundang-undangan.

Penginderaan jauh merupakan salah satu kompetensi utama yang dimiliki oleh LAPAN. Penginderaan jauh adalah ilmu dan seni untuk mendapatkan informasi mengenai objek, daerah, atau gejala dengan cara menganalisis data yang diperoleh menggunakan alat tanpa kontak langsung dengan objek, daerah, atau gejala tersebut [2]. Kegiatan berbasis penginderaan jauh di LAPAN diawali dengan eksperimental penerimaan data satelit resolusi rendah National Oceanic and Atmospheric Administration (NOAA) dan Geostationer Meteorology 
Satelit (GMS) yang dimanfaatkan untuk pemantauan kondisi lingkungan. Fase eksperimental penerimaan data penginderaan jauh terus meningkat hingga kini telah beroperasional untuk data satelit resolusi rendah hingga sangat tinggi yang diselenggarakan oleh Pusat Teknologi dan Data Penginderaan Jauh (Pustekdata). Data operasional tersebut digunakan untuk kegiatan litbang maupun pelayanan pengguna. Seiring dengan berkembangnya kebutuhan data spasial maka kegiatan penginderaan jauh pun semakin meningkat. Data yang sudah operasional tersedia saat ini di Pustekdata merupakan data dari berbagai resolusi yang diterima melalui akuisisi stasiun bumi milik LAPAN maupun pengadaan data.

Dalam perjalanan operasional data penginderaan jauh di Pustekdata, LAPAN mengoperasikan Bank Data Penginderaan Jauh yang dimulai sejak awal tahun 1990. Bank Data Penginderaan Jauh tersebut selanjutnya diberi nama Bank Data Penginderaan Jauh Nasional (BDPJN) yang gunanya untuk memfasilitasi kebutuhan data penginderaan jauh nasional. Selain itu, BDPJN dibangun juga untuk menghasilkan sistem kerja yang terintegrasi diantara tiga kegiatan utama di Pustekdata (lihat Gambar 1) yaitu akuisisi dan pengembangan teknologi stasiun bumi, pengolahan data penginderaan jauh, dan pengelolaan data penginderaan jauh.

BDPJN adalah suatu sistem di bawah Pustekdata yang memiliki fungsi mengumpulkan, memelihara, memutakhirkan, dan mendistribusikan metadata dan data penginderaan jauh wilayah Indonesia; menyediakan data penginderaan jauh jauh dengan tutupan awan minimal/bebas awan setiap tahun untuk seluruh wilayah Indonesia; menyediakan informasi mengenai kualitas data penginderaan jauh dalam bentuk metadata dan/atau riwayat data; memberi supervisi terkait pemanfaataan data penginderaan jauh; memberi masukan kepada pemerintah terkait kebijakan pengadaan, pemanfaatan, dan penguasaan teknologi dan data penginderaan jauh; membangun sistem akses data spasial yang terintegrasi dengan sistem akses Jaringan Data Spasial Nasional (JDSN) dan menyediakan akses data spasial kepada masyarakat sesuai peraturan perundangan yang berlaku; serta menyediakan fasilitas pengolahan data penginderaan jauh bagi para pengguna di luar LAPAN. BDPJN memiliki sepuluh proses bisnis operasional yaitu akuisisi dan penyimpanan data, ekstraksi metadata, pengolahan level data, mosaik data, pelayanan data, diseminasi data, remedia data arsip, supervisi pelayanan, dan pemberian rekomendasi.

Pustekdata LAPAN sebagai suatu organisasi yang telah menjalankan operasional pelayanan data penginderaan jauh melalui BDPJN membutuhkan suatu dokumen formal sebagai suatu perencanaan jangka panjang dalam pengembangan sistem yang mendukung dan memperkuat tugas dan fungsi kelembagaannya. Pada tahun 2011, Pustekdata menyusun Master Plan dan Blue Print Teknologi Informasi (TI) BDPJN tahun 2012-2016 sebagai dokumen dasar yang mengatur proses bisnis, kebutuhan sumber daya manusia, pengembangan infrastruktur, dan engineering detailed design infrastruktur BDPJN. Selanjutnya, Pustekdata juga telah menyusun Master Plan Manajemen BDPJN yang fungsinya dapat menghasilkan rekomendasi terkait kebijakan penyusunan organisasi yang paling sesuai, penentuan misi sistem akuisisi data, pengolahan dan pengelolaan data.

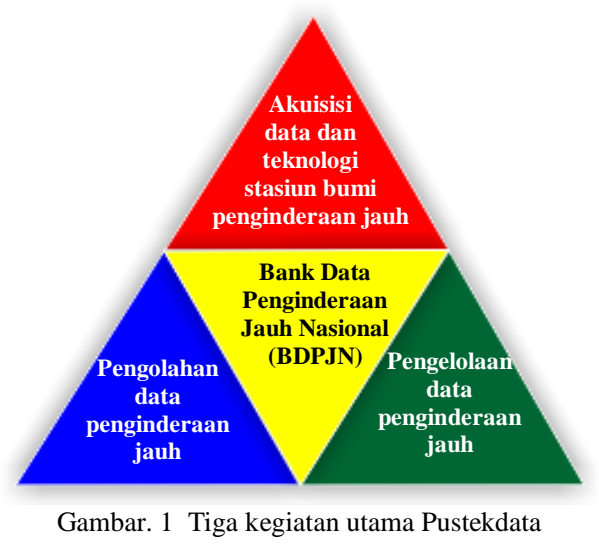

Blue Print TI BDPJN berisi panduan kerangka kerja suatu Data Center Bank Data Penginderaan Jauh di Pustekdata. Bank Data Penginderaan Jauh merupakan inti layanan yang diselenggarakan oleh Pustekdata LAPAN sebagai organisasi yang bergerak di bidang pengumpulan data penginderaan jauh. Adapun layanan utama yang diberikan oleh Bank Data Penginderaan Jauh yaitu business continuance infrastructure (infrastruktur yang menjamin kelangsungan pelayanan), data center security infrastructure (infrastruktur keamanan bank data), application optimization (optimisasi aplikasi), IP infrastructure (Infrastruktur IP), intelligent network services (layanan jaringan), dan media penyimpanan [3].

BDPJN memiliki target yang tertuang pada Master Plan TI dan Manajemen BDPJN. Target yang tercantum pada Master Plan tersebut yaitu Pustekdata menjadi penyedia data penginderaan jauh secara nasional, terjaminnya ketersediaan data penginderaan jauh satelit yang memenuhi kebutuhan nasional, dan terjaminnya kualitas dan kuantitas pemanfaatan data penginderaan jauh satelit secara nasional. Diperlukan suatu kajian untuk mengevaluasi apakah kegiatan yang telah dioperasionalkan hingga saat ini sudah menyesuaikan dengan implementasi dari Master Plan yang telah dibangun. Target-target yang tercantum pada Master Plan TI dan Manajemen BDPJN dapat dijadikan parameter untuk mengukur keberhasilan implementasi Master Plan TI dan Manajemen BDPJN yang telah dioperasionalkan hingga saat ini.

\section{METODOLOGI}

Metode yang akan digunakan untuk melakukan analisa, sebagai berikut: 


\section{A. Studi Literatur}

Studi literatur dilakukan untuk mengumpulkan referensi yang dibutuhkan sebagai informasi untuk menunjang analisa yang akan digunakan dalam penelitian ini. Telah banyak penelitian yang dilakukan untuk melakukan evaluasi terhadap suatu sistem informasi yang telah dioperasionalkan. Beberapa diantaranya adalah penggunaan Model DeLone dan McLean untuk mengukur kesuksesan implementasi E-procurement Kota Surabaya [4], E-Government Kota Pekalongan [5], sistem informasi pos pada PT. Pos Indonesia (Persero) Divisi Regional VI Semarang [6], sistem informasi kemahasiswaan (SIKMA) di Universitas Atma Jaya Yogyakarta [7], website fakultas ilmu komputer Universitas Brawijaya [8], sistem informasi akuntansi Accurate [9], System Application and Product (SAP) pada PT Multimas Nabati Asahan [10], dan sistem informasi absensi online di STIKOM Bali [11].

\section{B. DeLone dan McLean}

Metode DeLone dan McLean digunakan untuk mengukur keberhasilan suatu sistem informasi [5]. Model DeLone dan McLean sudah baik dan banyak dikenal untuk menilai kesuksesan suatu sistem informasi [12]. Metode ini telah banyak dilakukan studi secara empiris, mengukur tidak hanya pada satu variabel saja namun secara menyeluruh karena setiap dimensi saling berhubungan. Model DeLone dan McLean memiliki 6 variabel evaluasi yaitu: information quality (kualitas informasi), system quality (kualitas sistem), service quality (kualitas layanan), use (pengguna), user satisfaction (kepuasan pengguna) dan net benefit (hasil akhir) [13]. Model pengukuran keberhasilan sistem informasi menggunakan metode DeLone dan McLean dapat dilihat pada Gambar 2.

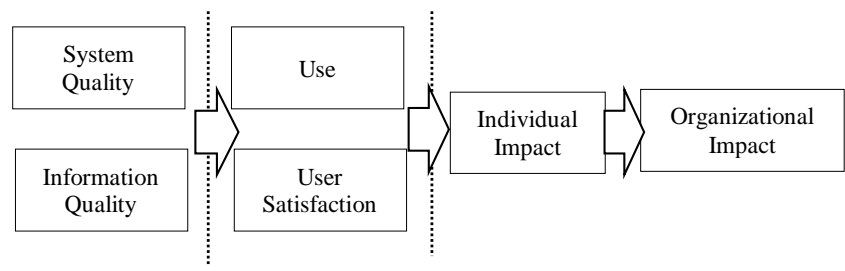

Gambar 2. Model pengukuran keberhasilan sistem informasi DeLone dan McLean [13]

Setiap variabel evaluasi pada Model DeLone dan McLean memiliki fokus sebagai berikut:

- Information Quality: Kualitas informasi yang digunakan pada sistem.

- System Quality: Kualitas sistem yang digunakan.

- Service Quality: Kualitas layanan.

- Use: Minat user untuk menggunakan suatu sistem.

- User Satisfaction: Kepuasan pengguna pada suatu sistem.

- Net benefit: Manfaat yang didapatkan oleh pengguna saat menggunakan suatu sistem dan setelah menggunakan sistem tersebut.
Metode DeLone dan McLean ini bertujuan untuk mengukur tingkat kesuksesan implementasi dari sebuah sistem informasi dalam mempermudah kinerja pegawai. Alur kerja yang digunakan pada penelitian ini dapat dilihat pada Gambar 3.

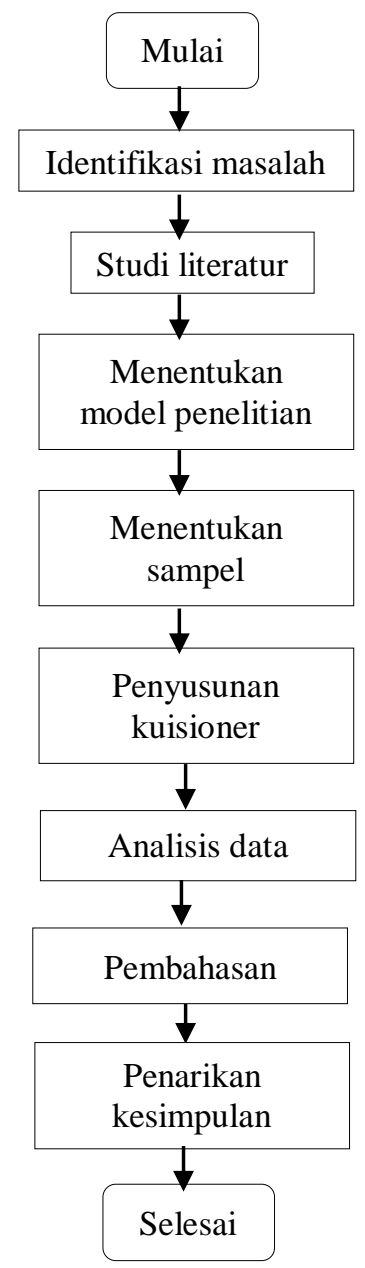

Gambar 3. Alur Penelitian

C. Slovin

Slovin adalah sebuah formula untuk menghitung jumlah sampel minimal. Sampel terlalu kecil dapat menyebabkan penelitian tidak dapat menggambarkan kondisi populasi yang sesungguhnya. Sementara sampel yang terlalu besar dapat mengakibatkan pemborosan biaya penelitian. Toleransi kesalahan (error) yang digunakan pada penelitian ini sebesar 5\% artinya tingkat akurasi penelitian ini sebesar 95\%. Formula Slovin [8] dapat dilihat pada persamaan (1). Pada penelitian ini, populasinya adalah 67 pegawai teknis di Pustekdata LAPAN sehingga diperoleh sampel yang digunakan sebanyak 58 responden.

$n=\frac{N}{1+N e^{2}}$

Keterangan: 
$N \quad=\quad$ Jumlah populasi

$n=$ Jumlah sampel

$e \quad=$ Batas toleransi kesalahan (error)

\section{Uji Validitas}

Uji validitas adalah ketepatan antara data yang terkumpul dengan data yang sesungguhnya terjadi pada objek yang diteliti [14]. Uji validitas ini dibutuhkan untuk mengukur keakuratan atau ketepatan sasaran kusioner dengan yang dibutuhkan [15].

$$
r_{x y}=\frac{N \sum X Y-\left(\sum X\right)\left(\sum Y\right)}{\sqrt{\left\{N \sum X^{2}-\left(\sum X\right)^{2}\right\}\left\{N \sum Y^{2}-\left(\sum Y\right)^{2}\right.}}
$$

Keterangan:

$r_{x y}=$ Koefisien korelasi/validitas

$X=$ Skor yang diperoleh subyek dari seluruh item

$Y=$ Skor total yang diperoleh dari seluruh item

$\Sigma X=$ Jumlah skor dalam distribusi $x$

$\Sigma Y=$ Jumlah skor dalam distribusi $y$

$\Sigma X^{2}=$ Jumlah kuadrat dalam skor distribusi $x$

$\Sigma Y^{2}=$ Jumlah kuadrat dalam skor distribusi $y$

$N=$ Banyaknya responden

\section{E. Uji Reliabilitas}

Reliabilitas digunakan untuk mengukur konsistensi suatu penelitian terhadap subjek dengan kondisi yang sama. Pengujian reliabilitas menggunakan uji Alpha Cronbach'C dilakukan untuk instrumen yang berbentuk esai, kuesioner, atau angket dengan skala bertingkat [16] Uji reliabilitas untuk alternatif jawaban lebih dari dua menggunakan uji Alpha Cronbach'C, yang nilainya akan dibandingkan dengan nilai koefisien reliabilitas minimal yang dapat diterima [17]. Instrumen penelitian dianggap reliabel atau konsisten dan baik jika memiliki nilai diatas 0,6 .

\section{F. Penyusunan Kuesioner}

Rancangan kuesioner ini dibuat berdasarkan target yang tercantum pada Master Plan TI dan Manajemen BDPJN tahun 2012-2016. Setiap pertanyaan diajukan untuk mengukur tingkat kesuksesan implementasi Master Plan BDPJN tersebut. Kuesioner Penelitian dapat dilihat pada Tabel 1.

TABEL I

KUESIONER PENELITIAN

\begin{tabular}{|c|l|l|}
\hline Komponen & Indikator & \multicolumn{1}{|c|}{ Pertanyaan Kuesioner } \\
\hline & & Ketersediaan peralatan \\
& & seperti peralatan stasiun \\
Information & & bumi, peralatan komunikasi \\
Quality & Completeness & data peralatan pengolahan \\
(Kualitas & & data, peralatan \\
Informasi) & & penyimpanan, pengelolaan \\
& & data dan pemeliharaan \\
& & sudah lengkap sesuai \\
\hline
\end{tabular}

\begin{tabular}{|c|c|c|}
\hline Komponen & Indikator & Pertanyaan Kuesioner \\
\hline & & kebutuhan. \\
\hline & & $\begin{array}{l}\text { Ketersediaan jenis data } \\
\text { multi resolusi (resolusi } \\
\text { rendah, menengah, tinggi, } \\
\text { dan sangat tinggi) untuk } \\
\text { berbagai kebutuhan. }\end{array}$ \\
\hline & Precision & $\begin{array}{l}\text { Peralatan yang dibutuhkan } \\
\text { sudah sesuai dengan fungsi } \\
\text { yang sebenarnya. }\end{array}$ \\
\hline & Reliability & $\begin{array}{l}\text { Peralatan yang digunakan } \\
\text { dapat diandalkan dalam } \\
\text { memenuhi kebutuhan } \\
\text { informasi data. }\end{array}$ \\
\hline & Currency & $\begin{array}{l}\text { Peralatan yang digunakan } \\
\text { selalu diperbaharui dan } \\
\text { sesuai dengan teknologi } \\
\text { saat ini. }\end{array}$ \\
\hline & $\begin{array}{l}\text { Format of } \\
\text { Output }\end{array}$ & $\begin{array}{l}\text { Data citra yang diperoleh } \\
\text { atau dikelola dapat } \\
\text { digunakan pada media lain. }\end{array}$ \\
\hline \multirow{5}{*}{$\begin{array}{l}\text { System } \\
\text { Quality } \\
\text { (Kualitas } \\
\text { Sistem) }\end{array}$} & $\begin{array}{l}\text { System } \\
\text { Flexibility }\end{array}$ & $\begin{array}{l}\text { Pengelolaan data untuk } \\
\text { memenuhi kebutuhan } \\
\text { instansi atau pengguna telah } \\
\text { menggunakan sistem TI. }\end{array}$ \\
\hline & $\begin{array}{l}\text { System } \\
\text { Integration }\end{array}$ & $\begin{array}{l}\text { Integrasi antara stasiun } \\
\text { bumi, pustekdata dengan } \\
\text { Jaringan Data Spasial } \\
\text { Nasional (JDSN) sudah } \\
\text { merealisasikan pengiriman } \\
\text { data dengan akses lebih } \\
\text { cepat dalam memanfaatkan } \\
\text { TI secara maksimal. } \\
\end{array}$ \\
\hline & $\begin{array}{l}\text { Time to } \\
\text { Respond }\end{array}$ & $\begin{array}{l}\text { Data resolusi rendah, } \\
\text { menengah, tinggi dan radar } \\
\text { dapat diakuisisi pada waktu } \\
\text { yang bersamaan dengan } \\
\text { adanya } 3 \text { sistem antena x- } \\
\text { band untuk menghindari } \\
\text { konflik waktu akuisisi di } \\
\text { beberapa lintasan satelit. }\end{array}$ \\
\hline & $\begin{array}{l}\text { Error } \\
\text { Recovery }\end{array}$ & $\begin{array}{l}\text { Sudah tersedia arsitektur } \\
\text { aplikasi yang menyediakan } \\
\text { sebuah kerangka kerja bagi } \\
\text { pustekdata Lapan sehingga } \\
\text { dapat diketahui aplikasi apa } \\
\text { saja yang dibutuhkan dalam } \\
\text { organisasi TI LAPAN. }\end{array}$ \\
\hline & $\begin{array}{l}\text { Convenience of } \\
\text { Access }\end{array}$ & $\begin{array}{l}\text { Data penginderaan jauh } \\
\text { mudah diakses pada sistem } \\
\text { yang sudah terintegrasi. }\end{array}$ \\
\hline
\end{tabular}




\begin{tabular}{|c|c|c|}
\hline Komponen & Indikator & Pertanyaan Kuesioner \\
\hline & Language & $\begin{array}{l}\text { Bahasa yang digunakan } \\
\text { pada sistem TI mudah } \\
\text { dipahami/dimengerti. }\end{array}$ \\
\hline \multirow{3}{*}{$\begin{array}{l}\text { Service } \\
\text { Quality } \\
\text { (Kualitas } \\
\text { Layanan) }\end{array}$} & Assurance & $\begin{array}{l}\text { Keamanan dalam } \\
\text { mengakses dan mengelola } \\
\text { data di berbagai sistem } \\
\text { terjamin baik yang bersifat } \\
\text { umum maupun privasi } \\
\text { instansi. }\end{array}$ \\
\hline & Empathy & $\begin{array}{l}\text { Panduan operasional } \\
\text { memberikan masukan } \\
\text { dalam melakukan langkah } \\
\text { penting strategis untuk } \\
\text { merumuskan rencana induk } \\
\text { hingga implementasi. }\end{array}$ \\
\hline & Responsiveness & $\begin{array}{l}\text { Sistem layanan memberikan } \\
\text { tanggapan sesuai yang di } \\
\text { harapkan. }\end{array}$ \\
\hline \multirow[b]{2}{*}{$\begin{array}{c}\text { Use } \\
\text { (Penggunaan) }\end{array}$} & $\begin{array}{l}\text { Daily Used } \\
\text { Time }\end{array}$ & $\begin{array}{l}\text { Pada link komunikasi data } \\
\text { sudah memiliki kapasitas } \\
\text { yang besar karena perkiraan } \\
\text { data yang ditransmisikan } \\
\text { dari stasiun bumi ke } \\
\text { pustekdata sekitar 50GB/ } \\
\text { hari. }\end{array}$ \\
\hline & $\begin{array}{l}\text { Frequency of } \\
\text { Use }\end{array}$ & $\begin{array}{l}\text { Selalu melakukan } \\
\text { penguatan kemampuan dan } \\
\text { kemandirian dalam } \\
\text { penguasaan teknologi } \\
\text { system stasiun bumi dan } \\
\text { pengolahan data } \\
\text { penginderaan jauh yang } \\
\text { berbasis inovasi dan open } \\
\text { source. }\end{array}$ \\
\hline \multirow{2}{*}{$\begin{array}{l}\text { User } \\
\text { Satisfaction } \\
\text { (Kepuasan } \\
\text { Pengguna) }\end{array}$} & $\begin{array}{l}\text { Repeat } \\
\text { Purchases }\end{array}$ & $\begin{array}{l}\text { Ketersediaan dan } \\
\text { kemudahan dalam } \\
\text { mengakses data } \\
\text { penginderaan jauh. }\end{array}$ \\
\hline & Repeat Visits & $\begin{array}{l}\text { Peningkatan kualitas } \\
\text { pelayanan dengan } \\
\text { pemanfaatan TI. }\end{array}$ \\
\hline \multirow{3}{*}{$\begin{array}{l}\text { Net Benefit } \\
\text { (Manfaat } \\
\text { Bersih) }\end{array}$} & $\begin{array}{l}\text { Speed of } \\
\text { accomplishing } \\
\text { task }\end{array}$ & $\begin{array}{l}\text { Dengan menggunakan } \\
\text { Jaringan Data Spasial } \\
\text { Nasional (JDSN) } \\
\text { pengiriman data akses } \\
\text { menjadi lebih cepat. }\end{array}$ \\
\hline & $\begin{array}{l}\text { Job } \\
\text { performance }\end{array}$ & $\begin{array}{l}\text { Kinerja dalam pengolahan } \\
\text { data menjadi lebih baik } \\
\text { dengan adanya penguatan } \\
\text { metodologi pengolahan data } \\
\text { dan penguatan hardware } \\
\text { dan software. }\end{array}$ \\
\hline & Effectiveness & $\begin{array}{l}\text { Dengan adanya efisiensi } \\
\text { biaya dapat menghindari } \\
\text { duplikasi sistem, mencegah } \\
\text { proyek yang bersifat } \\
\text { sporadis serta menjamin } \\
\text { setiap pengadaan TI } \\
\text { memiliki justifikasi yang } \\
\text { jelas. }\end{array}$ \\
\hline
\end{tabular}

\begin{tabular}{|c|c|c|}
\hline Komponen & Indikator & Pertanyaan Kuesioner \\
\hline & Ease of Job & $\begin{array}{l}\text { Kemudahan saat mengakses } \\
\text { data Penginderaan Jauh } \\
\text { pada sistem yang sudah } \\
\text { terintegrasi }\end{array}$ \\
\hline & $\begin{array}{l}\text { Usefulness in } \\
\text { Work }\end{array}$ & $\begin{array}{l}\text { Menjalin kerjasama, } \\
\text { sosialisasi dan pendidikan } \\
\text { dengan stakeholder strategis } \\
\text { Nasional sangat berguna } \\
\text { untuk meningkatkan } \\
\text { kontribusi penerapan } \\
\text { penelitian dan } \\
\text { pengembangan pada } \\
\text { prioritas pembangunan } \\
\text { nasional. }\end{array}$ \\
\hline
\end{tabular}

\section{HASIL DAN PEMBAHASAN}

\section{A. Pengumpulan Data}

Responden diambil dari dua bidang yang ada di Pustekdata LAPAN, yaitu Bidang Diseminasi dengan presentase sebesar $58,6 \%$ dan Bidang Program dan Fasilitas dengan presentase sebesar $41,4 \%$ dari total 58 responden.

\section{B. Hasil Uji Validitas}

Uji validitas (lihat Tabel 2) menggunakan correcteditem total correlation dimana item pertanyaan dinyatakan valid jika memiliki nilai $r$ hitung lebih besar dari $r$ tabel. Nilai $r$ tabel yang digunakan pada penelitian ini adalah 0,259 yang di dapat dari tabel nilai kritis $\mathrm{R}$ Pearson dengan signifikansi $5 \%$.

TABEL II

HASIL UJI VALIDITAS

\begin{tabular}{|c|c|c|}
\hline Kode & Hasil Uji & Keterangan \\
\hline IQ1.1 & 0,617 & Valid \\
\hline IQ1.2 & 0,695 & Valid \\
\hline IQ2 & 0,733 & Valid \\
\hline IQ3 & 0,700 & Valid \\
\hline IQ4 & 0,557 & Valid \\
\hline IQ5 & 0,368 & Valid \\
\hline SQ1 & 0,729 & Valid \\
\hline SQ2 & 0,693 & Valid \\
\hline SQ3 & 0,626 & Valid \\
\hline SQ4 & 0,615 & Valid \\
\hline SQ5 & 0,734 & Valid \\
\hline SQ6 & 0,683 & Valid \\
\hline SEQ1 & 0,683 & Valid \\
\hline SEQ2 & 0,638 & Valid \\
\hline SEQ3 & 0,659 & Valid \\
\hline U1 & 0,559 & Valid \\
\hline U2 & 0,664 & Valid \\
\hline US1 & 0,734 & Valid \\
\hline US2 & 0,719 & Valid \\
\hline NB1 & 0,575 & Valid \\
\hline NB2 & 0,593 & Valid \\
\hline NB3 & 0,631 & Valid \\
\hline NB4 & 0,743 & Valid \\
\hline NB5 & 0,550 & Valid \\
\hline & & \\
\hline
\end{tabular}




\section{Hasil Uji Reliabilitas}

Pengujian reliabilitas dalam penelitian ini menggunakan teknik Alpha Cronbach'C. Instrumen penelitian dianggap reliabel atau konsisten dan baik jika memiliki nilai diatas 0,6 . Kesimpulan hasil uji reliabilitas (lihat Tabel 3) adalah instrumen penelitian sudah reliabel dengan tingkat reliabilitas di atas 0,8 .

TABEL III

HASIL UJI RELIABILITAS

\begin{tabular}{|l|l|}
\hline \multicolumn{1}{|c|}{ Variabel } & \multicolumn{1}{c|}{ Tingkat Reliabilitas } \\
\hline Kualitas Informasi (KI) & 0,846 \\
\hline Kualitas Sistem (KS) & 0,844 \\
\hline Kualitas Layanan (KL) & 0,842 \\
\hline Penggunaan(P) & 0,871 \\
\hline Kepuasaan Pengguna (KP) & 0,858 \\
\hline Manfaat Bersih (MB) & 0,829 \\
\hline
\end{tabular}

\section{Hasil Analisis Variabel}

Analisis dekskriptif yang dilakukan untuk melakukan analisis kualitas variabel yaitu menghitung nilai rata-rata (mean), standar deviasi (SD), dan penentuan interval atau rentang skala setiap indikator. Interval yang digunakan yaitu mean - 1.5 SD, mean - 0.5 SD, mean + 0.5 SD, dan Mean + 1.5 SD

\section{1) Analisis Variabel Kualitas Informasi}

Dari hasil perhitungan analisis deskriptif (Tabel 4) dibawah ini diketahui bahwa mean dari setiap indikator:

- IQ1.1 sebesar 3,94 atau berada pada interval 3,67 - 4,20 yang berarti tingkat kesuksesannya adalah Cukup atau Sedang.

- IQ1.2 sebesar 4,18 atau berada pada interval 3,84 - 4,51 yang berarti tingkat kesuksesannya adalah Cukup atau Sedang.

- IQ2 sebesar 3,93 atau berada pada interval 3,61 4,24 yang berarti tingkat kesuksesannya adalah Cukup atau Sedang.

- IQ3 sebesar 3,91 atau berada pada interval 3,60 4,21 yang berarti tingkat kesuksesannya adalah Cukup atau Sedang.

- IQ4 sebesar 3,43 atau berada pada interval 3,06 3,79 yang berarti tingkat kesuksesannya adalah Cukup atau Sedang.

- IQ5 sebesar 4,17 atau berada pada interval 3,92 4,41 yang berarti tingkat kesuksesannya adalah Cukup atau Sedang.

TABEL IV

HASIL KATEGORI INDIKATOR VARIABEL KUALITAS INFORMASI

\begin{tabular}{|c|c|}
\hline Indikator & Cukup \\
\hline IQ1.1 & $\mathbf{3 , 6 7} \geq \boldsymbol{X}<\mathbf{4 , 2 0}$ \\
\hline IQ1.2 & $\mathbf{3 , 8 4} \geq \boldsymbol{X}<\mathbf{4 , 5 1}$ \\
\hline IQ2 & $\mathbf{3 , 6 1} \geq \boldsymbol{X}<\mathbf{4 , 2 4}$ \\
\hline IQ3 & $\mathbf{3 , 6 0} \geq \boldsymbol{X}<\mathbf{4 , 2 1}$ \\
\hline IQ4 & $\mathbf{3 , 0 6} \geq \boldsymbol{X}<\mathbf{3 , 7 9}$ \\
\hline IQ5 & $\mathbf{3 , 9 2} \geq \boldsymbol{X}<\mathbf{4 , 4 1}$ \\
\hline
\end{tabular}

Kemudian dilakukan analisis korelasi terhadap setiap variabel dengan menggunakan Pearson's product moment (lihat Tabel 5). Variabel kualitas informasi memiliki nilai korelasi positif 0,563 yang menunjukkan bahwa korelasi antara kualitas Informasi dan penggunaan berada dalam kategori sedang. Sementara perolehan nilai Sig. (2-tailed) adalah sebesar $0,000<0,05$ yang berarti terdapat korelasi yng signifikan antara variable kualitas informasi dengan variable penggunaan.

TABEL V

HASIL ANALISIS KORELASI VARIABEL KUALITAS INFORMASI DENGAN VARIABEL PENGGUNAAN

\begin{tabular}{|c|c|c|c|}
\hline Variabel & $\boldsymbol{X}$ & $\boldsymbol{Y}$ & Sig. (2-tailed) \\
\hline $\begin{array}{c}\text { Kualitas Informasi } \\
(\boldsymbol{X})\end{array}$ & 1 & 0,563 & 0,000 \\
\hline Penggunaan $(\boldsymbol{Y})$ & 0,563 & 1 & 0,000 \\
\hline
\end{tabular}

Nilai korelasi (lihat Tabel 6) adalah positif 0,644 yang menunjukkan bahwa korelasi antara Kualitas Informasi dengan kepuasan pengguna berada dalam kategori kuat, sementara nilai positif mengindikasikan pola hubungan yang searah. Perolehan nilai Sig. (2-tailed) adalah sebesar $0,000<0,005$ yang menandakan bahwa hubungan yang terjadi adalah signifikan sehingga setiap perubahan baik berupa peningkatan atau penurunan variabel di kualitas informasi akan berdampak secara langsung pada variabel kepuasan pengguna.

TABEL VI

HASIL ANALISIS KORELASI VARIABEL KUALITAS INFORMASI DENGAN VARIABEL KEPUASAN PENGGUNA

\begin{tabular}{|c|c|c|c|}
\hline Variabel & $\boldsymbol{X}$ & $\boldsymbol{Y}$ & Sig. (2-tailed) \\
\hline $\begin{array}{c}\text { Kualitas Informasi } \\
(\boldsymbol{X})\end{array}$ & 1 & 0,644 & 0,000 \\
\hline $\begin{array}{c}\text { Kepuasan Pengguna } \\
(\boldsymbol{Y})\end{array}$ & 0,644 & 1 & 0,000 \\
\hline
\end{tabular}

\section{2) Analisis Variabel Kualitas Sistem}

Dari hasil perhitungan analisis deskriptif dibawah ini diketahui bahwa mean dari setiap indicator (lihat Tabel 7):

- $\quad$ SQ1 sebesar 3,94 atau berada pada interval 3,59 4,28 yang berarti tingkat kesuksesannya adalah Cukup atau Sedang.

- $\quad$ SQ2 sebesar 3,68 atau berada pada interval 3,32 4,03 yang berarti tingkat kesuksesannya adalah Cukup atau Sedang.

- $\quad$ SQ3 sebesar 3,94 atau berada pada interval 3,67 4,20 yang berarti tingkat kesuksesannya adalah Cukup atau Sedang.

- $\quad$ SQ4 sebesar 3,43 atau berada pada interval 2,98 - 3.87 yang berarti tingkat kesuksesannya adalah Cukup atau Sedang.

- $\quad$ SQ5 sebesar 4,00 atau berada pada interval 3,63 4,36 yang berarti tingkat kesuksesannya adalah Cukup atau Sedang. 
- SQ6 sebesar 3,75 atau berada pada interval 3,40 4,00 yang berarti tingkat kesuksesannya adalah Cukup atau Sedang.

TABEL VII

HASIL KATEGORI INDIKATOR VARIABEL KUALITAS SISTEM

\begin{tabular}{|c|c|}
\hline Indikator & Cukup \\
\hline SQ1 & $\mathbf{3 , 5 9} \geq \boldsymbol{X}<\mathbf{4 , 2 8}$ \\
\hline SQ2 & $\mathbf{3 , 3 2} \geq \boldsymbol{X}<\mathbf{4 , 0 3}$ \\
\hline SQ3 & $\mathbf{3 , 6 7} \geq \boldsymbol{X}<\mathbf{4 , 2 0}$ \\
\hline SQ4 & $\mathbf{2 , 9 8} \geq \boldsymbol{X}<\mathbf{3 , 8 7}$ \\
\hline SQ5 & $\mathbf{3 , 6 3} \geq \boldsymbol{X}<\mathbf{4 , 3 6}$ \\
\hline SQ6 & $\mathbf{3 , 4 0} \geq \boldsymbol{X}<\mathbf{4 , 0 0}$ \\
\hline
\end{tabular}

Kemudian pada variabel kualitas sistem ini memiliki nilai korelasi adalah 0,502 (lihat Tabel 8) yang menunjukkan bahwa korelasi antara kualitas sistem dan pengguna dalam kategori sedang yang berarti setiap perubahan di variabel kualitas sistem akan berpengaruh pada variabel penggunaan, tetapi tidak terlalu berdampak kuat atau terasa pada variabel tersebut. Pada nilai sig. (2tailed) di dapat sebesar $0,000<0,005$ yang berarti terdapat data korelasi yang siginifikan anatara variabel kualitas system dengan penggunaan.

\section{TABEL VIII}

HASIL KATEGORI INDIKATOR VARIABEL KUALITAS SISTEM

\begin{tabular}{|c|c|c|c|}
\hline Variabel & $\boldsymbol{X}$ & $\boldsymbol{Y}$ & Sig. (2-tailed) \\
\hline $\begin{array}{c}\text { Kualitas Sistem } \\
(\boldsymbol{X})\end{array}$ & 1 & 0,502 & 0,000 \\
\hline $\begin{array}{c}\text { Penggunaan } \\
(\boldsymbol{Y})\end{array}$ & 0,502 & 1 & 0,000 \\
\hline
\end{tabular}

Variabel kualitas sistem dengan variabel kepuasan pengguna memiliki nilai korelasi positif 0,718 (lihat Tabel 9) yang menunjukkan bahwa korelasi antara kualitas system dengan kepuasan pengguna berada dalam kategori kuat, sehingga setiap peningkatan atau penurunan di variabel kualitas system akan berpengaruh langsung kepada vriabel kepuasan pengguna. Perolehan nilai sig.(2tailed) sebesar 0,000<0,005 menandakan bahwa hubungan yang terjadi adalah signifikan.

TABEL IX

HaSil ANALISIS KoRELASI VARIABEL KUALITAS Sistem DENGAN VARIABEL KEPUASAAN PENGGUNA

\begin{tabular}{|c|c|c|c|}
\hline Variabel & $\boldsymbol{X}$ & $\boldsymbol{Y}$ & Sig. (2-tailed) \\
\hline $\begin{array}{c}\text { Kualitas Sistem } \\
(\boldsymbol{X})\end{array}$ & 1 & 0,718 & 0,000 \\
\hline $\begin{array}{c}\text { Kepuasan Pengguna } \\
(\boldsymbol{Y})\end{array}$ & 0,718 & 1 & 0,000 \\
\hline
\end{tabular}

\section{3) Analisis Variabel Kualitas Layanan}

Dari hasil perhitungan analisis deskriptif dibawah ini diketahui bahwa mean dari setiap indicator (Tabel 10):

- $\quad$ SEQ1 sebesar 3,74 atau berada pada interval 3,36 - 4,11 yang berarti tingkat kesuksesannya adalah Cukup atau Sedang.
- $\quad$ SEQ2 sebesar 3,62 atau berada pada interval 3,23 - 4,00 yang berarti tingkat kesuksesannya adalah Cukup atau Sedang.

- $\quad$ SEQ3 sebesar 3,81 atau berada pada interval 3,51 - 4,10 yang berarti tingkat kesuksesannya adalah Cukup atau Sedang.

TABEL X

HASIL KATEGORI INDIKATOR VARIABEL KUALITAS LAYANAN

\begin{tabular}{|c|c|}
\hline Indikator & Cukup \\
\hline SEQ1 & $\mathbf{3 , 3 6} \geq \boldsymbol{X}<\mathbf{4 , 1 1}$ \\
\hline SEQ2 & $\mathbf{3 , 2 3} \geq \boldsymbol{X}<\mathbf{4 , 0 0}$ \\
\hline SEQ3 & $\mathbf{3 , 5 1} \geq \boldsymbol{X}<\mathbf{4 , 1 0}$ \\
\hline
\end{tabular}

Dari tabel dibawah ini diketahui nilai sig.(2-tailed) antara variabel kualitas layanan dengan variabel penggunaan adalah sebesar $0,000<0,005$ yang berarti terdapat korelasi yang signifikan (lihat Tabel 11). Kemudian nilai korelasinya adalah positif 0,527 menunjukkan bahwa korelasi antara kualitas layanan dengan penggunaan berada dalam kategori sedang. Maka peningkatan atau penurunan pada variabel kualitas layanan tidak berpengaruh banyak pada variabel penggunaan.

TABEL XI

HASIL KATEGORI INDIKATOR VARIABEL KUALITAS LAYANAN

\begin{tabular}{|c|c|c|c|}
\hline Variabel & $\boldsymbol{X}$ & $\boldsymbol{Y}$ & Sig. (2-tailed) \\
\hline $\begin{array}{c}\text { Kualitas Layanan } \\
(\boldsymbol{X})\end{array}$ & 1 & 0,527 & 0,000 \\
\hline $\begin{array}{c}\text { Penggunaan } \\
(\boldsymbol{Y})\end{array}$ & 0,527 & 1 & 0,000 \\
\hline
\end{tabular}

Dari tabel dibawah ini diketahui nilai sig.(2-tailed) antara variabel kualitas layanan dengan variabel penggunaan adalah sebesar $0,000<0,005$ yang berarti terdapat korelasi yang signifikan (lihat Tabel 12). Kemudian nilai korelasinya adalah positif 0,686 menunjukkan bahwa korelasi antara kualitas layanan dengan kepuasan pengguna berada dalam kategori kuat. Maka jika terjadi perubahan pada kualitas layanan seperti peningkatan atau penurunan akan sangat berpengaruh langsung pada variabel kepuasan pengguna.

TABEL XII

HASIL ANALISIS KORELASI VARIABEL KUALITAS LAYANAN DENGAN VARIABEL KEPUASAN PENGGUNA

\begin{tabular}{|c|c|c|c|}
\hline Variabel & X & Y & Sig. (2-tailed) \\
\hline $\begin{array}{c}\text { Kualitas Layanan } \\
\text { (X) }\end{array}$ & 1 & 0,686 & 0,000 \\
\hline $\begin{array}{c}\text { Kepuasan Pengguna } \\
\text { (Y) }\end{array}$ & 0,686 & 1 & 0,000 \\
\hline
\end{tabular}

\section{4) Analisis Variabel Penggunaan}

Dari hasil perhitungan analisis deskriptif dibawah ini diketahui bahwa mean dari setiap indicator (Tabel 13):

- U1 sebesar 3,87 atau berada pada interval 3,55 4,18 yang berarti tingkat kesuksesannya adalah Cukup atau Sedang. 
- $\quad \mathrm{U} 2$ sebesar 3,86 atau berada pada interval 3,55 4,16 yang berarti tingkat kesuksesannya adalah Cukup atau Sedang.

TABEL XIII

HASIL KATEGORI INDIKATOR VARIABEL PENGGUNAAN

\begin{tabular}{|c|c|}
\hline Indikator & Cukup \\
\hline $\mathrm{U} 1$ & $\mathbf{3 , 5 5} \geq X<\mathbf{4 , 1 8}$ \\
\hline $\mathrm{U} 2$ & $\mathbf{3 , 5 5} \geq X<\mathbf{4 , 1 6}$ \\
\hline
\end{tabular}

Kemudian pada hasil analisis korelasi variabel penggunaan memiliki hubungan yang positif terhadap variabel kepuasan pengguna dengan nilai korelasi adalah 0,529 (lihat Tabel 14) dan variabel manfaat bersih dengan nilai korelasi adalah 0,543 (lihat Tabel 15). Kedua besaran angka korelasi tersebut menunjukkan bahwa korelasi antara variabel penggunaan dengan kepuasan pengguna dan manfaat bersih berada dalam kategori sedang. Hal ini menunjukkan jika terjadi perubahan seperti peningkatan atau penurunan pada variabel penggunaan tidak akan berdampak terlalu besar pada variabel kepuasan pengguna dan manfaat bersih.

TABEL XIV

HASIL KATEGORI INDIKATOR VARIABEL PENGGUNAAN

\begin{tabular}{|c|c|c|c|}
\hline Variabel & $\boldsymbol{X}$ & $\boldsymbol{Y}$ & Sig. (2-tailed) \\
\hline $\begin{array}{c}\text { Penggunaan } \\
(\boldsymbol{X})\end{array}$ & 1 & 0,529 & 0,000 \\
\hline $\begin{array}{c}\text { Kepuasan Pengguna } \\
(\boldsymbol{Y})\end{array}$ & 0,529 & 1 & 0,000 \\
\hline
\end{tabular}

TABEL XV

HASIl ANALISIS KoRELASI VARIABEL PENGGUNAAN DENGAN VARIABEL MANFAAT BERSIH

\begin{tabular}{|c|c|c|c|}
\hline Variabel & $\boldsymbol{X}$ & $\boldsymbol{Y}$ & Sig. (2-tailed) \\
\hline $\begin{array}{c}\text { Penggunaan } \\
(\boldsymbol{X})\end{array}$ & 1 & 0,543 & 0,000 \\
\hline $\begin{array}{c}\text { Manfaat Bersih } \\
(\boldsymbol{Y})\end{array}$ & 0,543 & 1 & 0,000 \\
\hline
\end{tabular}

5) Analisis Variabel Kepuasan Pengguna

Dari hasil perhitungan analisis deskriptif dibawah ini diketahui bahwa mean dari setiap indicator (Tabel 16):

- US1 sebesar 4,05 atau berada pada interval 3,77 4,32 yang berarti tingkat kesuksesannya adalah Cukup atau Sedang.

- US2 sebesar 4,01 atau berada pada interval 3,70 4,31 yang berarti tingkat kesuksesannya adalah Cukup atau Sedang.

TABEL XVI

HASIL KATEGORI INDIKATOR VARIABEL KEPUASAAN PENGGUNA

\begin{tabular}{|c|c|}
\hline Indikator & Cukup \\
\hline US1 & $\mathbf{3 , 7 7} \geq X<\mathbf{4 , 3 2}$ \\
\hline US2 & $\mathbf{3 , 7 0} \geq X<\mathbf{4 , 3 1}$ \\
\hline
\end{tabular}

Kemudian nilai korelasi yang diperoleh pada variabel kepuasan pengguna terhadap variabel manfaat bersih adalah positif 0,757 yang menunjukkan bahwa korelasi anatara kepuasan pengguna dengan manfaat bersih berada dalam kategori kuat (lihat Tabel 17). Maka setiap perubahan yang terjadi pada variabel kepuasan pengguna akan sangat berdampak secara langsung pada variabel manfaat bersih, sehingga meningkatnya kepuasan pengguna akan membuat manfaat bersih meningkat.

TABEL XVII

HASIL ANALISIS KORELASI VARIABEL PENGGUNA DENGAN VARIABEL MANFAAT BERSIH

\begin{tabular}{|c|c|c|c|}
\hline Variabel & X & Y & Sig. (2-tailed) \\
\hline $\begin{array}{c}\text { Kepuasan Pengguna } \\
(\mathrm{X})\end{array}$ & 1 & 0,757 & 0,000 \\
\hline $\begin{array}{c}\text { Manfaat Bersih } \\
(\mathrm{Y})\end{array}$ & 0,757 & 1 & 0,000 \\
\hline
\end{tabular}

\section{6) Analisis Variabel Manfaat Bersih}

Dari hasil perhitungan analisis deskriptif dibawah ini diketahui bahwa mean dari setiap indicator (Tabel 18):

- NB1 sebesar 3,84 atau berada pada interval 3,52 4,15 yang berarti tingkat kesuksesannya adalah Cukup atau Sedang.

- NB2 sebesar 4,01 atau berada pada interval 3,73 4,28 yang berarti tingkat kesuksesannya adalah Cukup atau Sedang.

- NB3 sebesar 3,56 atau berada pada interval 3,20 4,91 yang berarti tingkat kesuksesannya adalah Cukup atau Sedang.

- $\quad$ NB4 sebesar 3,89 atau berada pada interval 3,56 - 4,21 yang berarti tingkat kesuksesannya adalah Cukup atau Sedang.

- NB5 sebesar 4,08 atau berada pada interval 3,74 4,41 yang berarti tingkat kesuksesannya adalah Cukup atau Sedang.

TABEL XVIII

HASIL KATEGORI INDIKATOR VARIABEL MANFAAT BERSIH

\begin{tabular}{|c|c|}
\hline Indikator & Cukup \\
\hline NB1 & $\mathbf{3 , 5 2} \geq \boldsymbol{X}<\mathbf{4 , 1 5}$ \\
\hline NB2 & $\mathbf{3 , 7 3} \geq \boldsymbol{X}<\mathbf{4 , 2 8}$ \\
\hline NB3 & $\mathbf{3 , 2 0} \geq \boldsymbol{X}<\mathbf{3 , 9 1}$ \\
\hline NB4 & $\mathbf{3 , 5 6} \geq \boldsymbol{X}<\mathbf{4 , 2 1}$ \\
\hline NB5 & $\mathbf{3 , 7 4} \geq \boldsymbol{X}<\mathbf{4 , 4 1}$ \\
\hline
\end{tabular}

\section{KESIMPULAN}

Berdasarkan analisa tentang kesuksesan implementasi Masterplan BDPJN manajemen dan IT menunjukkan tingkat kesuksesan yang cukup, sehingga masih diperlukan peningkatan untuk mengoptimalkan pekerjaan dan memberikan layanan yang lebih baik bagi pengguna.

Dari hasil korelasi yang didapat dengan menggunakan perhitungan formula SPSS menunjukkan hubungan positif dan signifikan pada semua variabel. Hal ini mengindikasikan bahwa pola hubungan yang terjadi adalah searah ketika suatu variabel mengalami perubahan 
seperti peningkatan atau penurunan maka variabel lain yang terhubung akan berdampak.

Dilihat dari tingkat korelasinya, kepuasan pengguna sangat berpengaruh pada kesuksesan implementasi masterplan BDPJN diikuti dengan meningkatnya kualitas sistem, kualitas layanan, dan kualitas informasi yang juga ikut mempengaruhinya. Selain itu, meningkatnya kepuasan pengguna maka akan berdampak pada manfaatmanfaat yang diberikan oleh sistem BDPJN sehingga dapat membantu meningkatkan dan mempermudah kinerja pegawai.

\section{UCAPAN TERIMA KASIH / ACKNOWLEDGMENT}

Penulis mengucapkan terima kasih kepada Kepala Pusat Teknologi dan Data Penginderaan Jauh LAPAN, Ir. Dedi Irawadi, telah mendukung penelitian ini serta kepada Kepala Kelompok Penelitian Pengelolaan dan Distribusi Data Penginderaan Jauh, Ir. Muchammad Muchlis, M.Si telah membantu tim kami dalam menyelesaikan penelitian ini.

\section{REFERENSI}

[1] Peraturan Kepala Lembaga Penerbangan dan Antariksa Nasional Republik Indonesia No. 8 Tahun 2015 tentang Organisasi dan Tata Kerja Lembaga Penerbangan dan Antariksa Nasional, Berita Negara Republik Indonesia No. 1573, 2017.

[2] R. W. K. Thomas M. Lillesand, Remote sensing and image interpretation, New York: John Wiley, 1979.

[3] Pustekdata LAPAN, "Laporan Penyusunan Blue Print Sistem Bank Data Penginderaan Jauh Nasional Tahun 2012-2016,” 2011.

[4] R. M. Pramadani and Mudjahidin, "Analisis Keberhasilan Eprocurement Pemerintah Kota Surabaya Menggunakan Information System Success Model," Jurnal Teknik POMITS, vol. 1, no. 1, pp 1-6, 2013.

[5] P. H. Saputro, A. D. Budiyanto and A. J. Santoso, "Model Delone and Mclean untuk Mengukur Kesuksesan E-Government Kota Pekalongan," Scientific Journal of Informatics, vol. 2, no. 1, pp. 1 8, Mei 2015.

[6] K. Yuliana, "Model Kesuksesan Sistem Informasi DeLone dan McLean untuk Evaluasi Sistem Informasi Pos pada PT. Pos Indonesia (Persero) Divisi Regional VI Semarang," Jurnal Ilmiah Infokam, vol. XII, no. 2, pp. 13-23, 2016.

[7] F. S. Rahayu, R. Apriliyanto and Y. S. P. W. Putro, "Analisis Kesuksesan Sistem Informasi Kemahasiswaan (SIKMA) dengan Pendekatan Model DeLone dan McLean," Indonesian Journal of Information Systems (IJIS), vol. I, no. 1, pp. 34-46, 2018

[8] L. H. Trihandayani, I. Aknuranda and Y. T. Mursityo, "Penerapan Model Kesuksesan DeLone dan McLean pada Wbsite Fakultas Ilmu Komputer (FILKOM) Universitas Brawijaya," Jurnal Pengembangan Teknologi Informasi dan Ilmu Komputer, vol. 2, no. 12, pp. 7074-7082, 2018

[9] J. M. Hudin and D. Riana, "Kajian Keberhasilan Penggunaan Sistem Informasi Accurate dengan Menggunakan Mode Kesuksesan Sistem Informasi DeLone dan McLean," Jurnal Sistem Informasi (Journal of Information System), vol. 12, no. 1, pp. 1-8 2016.

[10] E. S. Panjaitan, D. T. R. J. Hutabarat, L. V. Hutabarat and D. Arisandy, "Analisis Model Kesuksesan Sistem Informasi Studi Kasus : Penggunaan SAP pada PT Multimas Nabati Asahan," Jurnal SIFO Mikroskil, vol. 18, no. 1, pp. 1-10, 2017.

[11] R. K. Wiyati and N. L. A. K. Y. Sarja, "Evaluasi Kesuksesan
Sistem Informasi Absensi Online Menggunakan Model DeLone McLean," Jurnal Media Aplikom, vol. 10, no. 2, pp. 135-157, Desember 2018.

[12] S. Mardiana, J. H. Tjakraatmadja and A. Aprianingsih, "DeLoneMcLean Information System Success Model Revisited: The Separation of Intention to Use - Use and the Integration of Technology Acceptance Models," International Journal of Economics and Financial Issues, vol. 5, pp. 172-182, 2015.

[13] E. R. M. William H. Delone, "The DeLone and McLean Model of Information Systems Success: A Ten-Year Update," Journal of Management Information Systems, vol. 19, pp. 9-30, 2003.

[14] H. Halin, "Pengaruh Kualitas Produk terhadap Kepuasan Pelanggan Semen Baturaja di Palembang pada PT Semen Baturaja (Persero) Tbk," Jurnal EcoMent Global, vol. 3, no. 2, pp. 167-182, 2018.

[15] Sutriyono, "Uji Validitas dan Reliabilitas Kuesioner Kepuasan Konsumen Pengujian Sampel Laboratorium Terpadu Fakultas Sains dan Teknologi UIN Sunan Kalijaga Yogyakarta," Integrated Lab Journal, vol. 4, no. 1, pp. 103-108, 2016.

[16] F. Yusup, "Uji Validitas dan Reliabilitas Instrumen Penelitian Kuantitatif," Jurnal Tarbiyah: Jurnal Ilmu Kependidikan, vol. 7, no. 1, pp. 17-23, 2018.

[17] I. Fanani, S. P. Djati and K. Silvanita, "Pengaruh Kepuasan Kerja dan Komitmen Organisasi terhadap Organizational Citizenship Behavior (OCB) (Studi Kasus RSU UKI)," Fundamental Management Journal, vol. 1, no. 04, pp. 40-53, Februari 2017. 